\title{
MENELISIK TINDAK PIDANA YANG BERKAITAN DENGAN KERAHASIAAN INTELIJEN NEGARA
}

\author{
Muhamamd Azil Maskur \\ Fakultas Hukum Universitas Negeri Semarang \\ azilmaskur85@mail.unnes.ac.id
}

\begin{abstract}
Abstrak
Tindak pidana yang terkait dengan intelijen negara telah diatur dalam KUHP dan Undang-undang Nomor 17 Tahun 2011 tentang Intelijen Negara. Pengaturan dalam KUHP bersifat umum terbingkai dalam bab yang terkait dengan kejahatan terhadap keamanan negara dan bab yang terkait dengan membuka rahasia negara. Sedangkan pengaturan dalam UU Intelijen Negara bersifat khusus yang diatur dalam Pasal 44, 45, 46 dan 47. Pidana maksimal yang dapat dijatuhkan adalah 10 tahun penjara dan dapat ditambah $1 / 3$ jika dilakukan oleh intelijen negara dalam keadaan perang. Ada beberapa kelemahan yuridis pengaturan tindak pidana terkait intelijen negara tersebut, sehingga perlu ada pembenahan dalam kebijakan formulasi pada masa yang akan datang. Pembaharuan tersebut terkait dengan kualifikasi delik, pengaturan terkait permufakatan jahat, pengaturan pidana jika tidak dibayar oleh korporasi.
\end{abstract}

Kata kunci: tindak pidana, intelijen negara.

\section{A. Pendahuluan}

Indonesia adalah negara yang besar dan dilahirkan atas keberagaman suku, ras dan agama. Jumlah pulaunya yang mencapai 17.504 (termasuk 9.634 pulau yang belum diberi nama, dan 6.000 pulau yang tidak berpenghuni), dan suku yang lebih dari $740 \mathrm{suku}$, serta agama dan kepercayaan yang beragam membuat bangsa ini menjadi negara yang kaya akan budaya. ${ }^{70}$

Keragaman suku, agama, budaya bangsa ini disatu sisi adalah suatu kekuatan tersendiri jika di manajemen dengan baik dan benar, akan tetapi disisi lain orang-orang yang tidak suka dengan kebhinekaan bangsa ini akan menggunakan perbedaan tersebut sebagai sarana untuk melakukan perongrongan,

70 http://sosbud.kompasiana.com/2011/03/01/20-keunggulan-indonesia-di-dunia diunduh pada tanggal 19 Mei 2012. 
seperti dengan mengadu domba. Upaya seperti ini telah ada dari zaman penjajahan Belanda sampai sekarang.

Fenomena yang terjadi akhir-akhair ini, yaitu perang antar suku di Papua tidak lain adalah upaya untuk mengantarkan bangsa ini pada disintegrasi bangsa. Faktor kekuatan yang sekaligus dipandang sebagai kelemahan oleh sebagian orang/kelompok inilah yang akhirnya melahirkan negara harus turun tangan untuk melakukan tindakan preventif. Tidakan preventif yang dilakukan, selain upaya non penal yaitu dengan dialog antara golongan, mengedepankan upaya musyawarah dan penyadaran akan pentingnya persatuan dan kesatuan, juga melalui operasi intelijen negara yang digunakan pemerintah sebagai upaya dini mengetahui berbagai kegiatan yang dimungkinkan berujung pada perongrongan Indonesia sebagai bangsa yang besar.

Walaupun upaya intelijen ini menimbulkan pro dan kontra, karena dianggap menyalahi dan melanggar Hak Asasi Manusia, akan tetapi demi kepentingan bangsa yang besar, maka pemerintah mengeluarkan Undang-undang tentang intelijen negara. Ada beberapa adagium jika menginginkan negara kuat maka rakyat harus dilemahkan, sebaliknya jika menginginkan rakyat kuat maka negara yang harus dilemahkan. Pendapat ini tentunya melihat realita sekarang yang muncul, akan tetapi cita-cita bangsa yaitu mewujudkan masyarakat madani (civil society) hanya akan tercapai jika adanya keseimbangan antara negara (state), masyarakat (society) dan pasar. ${ }^{71}$

Penulis tidak akan terjebak pada pro dan kontra soal intelijen, akan tetapi penulis akan jernih melihat bahwa tindak pidana yang berkaitan dengan pembocoran rahasia intelijen adalah suatu hal yang serius sehingga memang perlu diatur sebagai upaya preventif melalui jalur penal disamping upaya non penal yang sudah dilakukan. ${ }^{72}$

71 Jimly Asshiddiqie, 2010, Konstitusi dan Konstitusionalisme Indonesia, Jakarta: Sinar Grafika, halaman 66.

${ }^{72}$ Upaya penanggulangan kejahatan dapat dilakukan melalui upaya penal dan non penal, upaya penal adalah melalui jalur hukum pidana, sedangkan upaya non penal adalah penanggulangan kejahatan yang tidak menggunakan jalur hukum pidana (Barda Nawawi Arief, 
Undang-undang intelijen negara ini diatur berbagai macam hal tentang intelijen negara, tidak terlepas juga pengaturan tentang tindak pidana yang berkaitan dengan intelijen negara seperti pembocoran rahasia negara. Berkaitan dengan latar belakang di atas, maka penulis mencoba mengkaji tentang tindak pidana yang berkaitan dengan intelijen negara ini

\section{B. Pembahasan}

\section{Tindak Pidana yang Berkaitan dengan Intelijen dan Tindak Pidana Politik}

Tindak pidana politik atau tindak pidana yang berkaitan denganpolitik tidak ada definisi yuridisnya, apalagi dalam KUHP sendiri tidak ada yang mengatur khusus tentang tindak pidana politik. Akan tetapi perkembangan negara sebagai bagian proses politik maka kejahatan terhadap negara oleh orang awam sering disebut sebagai kejahatan politik. Tindak pidana politik ini dalam perkembangannya tidak hanya diatur dalam KUHP akan tetapi juga diluar KUHP yang disebut hukum pidana khusus ${ }^{73}$.

Abdul Hakim Garuda Nusantara menyatakan, pendefinisian perbuatan pidana yang dikualifikasikan sebagai pidana politik senantiasa dipengaruhi oleh tantangan yang dihadapi oleh negara dalam kurun waktu tertentu dan persepsi dari elite pemegang kekuasaan negara terhadap tantangan tersebut ${ }^{74 .}$

Definisi lain mengenai kejahatan politik adalah menurut konferensi internasional tentang hukum pidana. Konferensi tersebut memberi pengertian kejahatan politik sebagai kejahatan yang menyerang organisasi maupun hak penduduk yang timbul dari berfungsinya negara tersebut. Pengertian tersebut juga belum menjelaskan siapa yang menjadi subyek hukum dan delik politik, apakah

2010, Bunga Rampai Kebijakan Hukum Pidana: Perkembangan Penyusunan Konsep KUHP Baru, Jakarta: kencana Prenada Media Group, halaman 42).

${ }^{73}$ Hukum pidana khusus adalah suatu aturan perundang-undangan dibidang tertentu, yang memiliki sanksi pidana, atau tindak-tindak pidana yang diatur dalam perundang-undangan khusus, diluar KUHP,juga memiliki ketentuan yang menyimpang dari KUHP (Aziz Syamsuddin, 2011, Tindak Pidana Khusus, Jakarta: Sinar Grafika, halaman 8)

74 Abdul Hakim Garuda Nusantara, Pidana Politik Seri Diskusi Hukum dan Politik, Devisi Pendidikan dan Kajian Strategis Yayasan Lembaga Bantuan Hukum Indonesia, (YLBHI), Jakarta, hlm.4. 
individu, korporasi, ataukah negara. Demikian pula organisasi mana yang dimaksud, sebab begitu banyak organisasi yang didirikan di suatu negara.

Menurut Piers Beirne dan James Messerschmidt kejahatan politik secara kriminologis dapat dibedakan dalam tiga bentuk. Pertama adalah kejahatan politik yang ditujukan kepada negara atau political crimes against the state. Kedua adalah kejahatan politik oleh negara atau domestic political crimes by the state. Ketiga adalah kejahatan politik internasional oleh negara atau international political crimes by the state.

Walaupun demikian sekedar pegangan untuk menentukan apakah suatu kejahatan termasuk sebagai kejahtan politik, parameter yang dapat digunakan adalah:

1. Perbuatan pidana tersebut ditujukan untuk mengubah tertib hukum yang berlaku di suatu negara;

2. Perbuatan pidana tersebut ditujukan kepada negara atau berfungsinya lembaga lembaga negara;

3. Perbuatan tersebut secara dominan menampakan motif dan tujuan politiknya;

4. Pelaku perbuatan mempunyai keyakinan bahwa dengan mengubah tertib hukum yang berlaku maka apa yang ingin dicapai adalah lebih baik dan keadaan yang berlaku sekarang.

Stephen Schaffer ${ }^{75}$, memberikan pernyataan yang sangat ekstrim, dimana schaffer menyebut bahwa semua kejahatan merupakan kejahatan politik. Memang apabila diruntut sampai kebelakang bahwa kejahatan pada hakikatnya merupakan perbuatan yang akan mengganggu keseimbangan sosial, dan keseimbangan sosial merupakan bagian dari keseimbangan negara maka jelas bahwa setiap kejahatan adalah perbuatan yang pada hakikatnya merugikan kepentingan negara sehingga dapat digolongkan kejahatan politik.

Kejahatan politik secara konsepsional menurut Dionysios Spinellis dikelompokkan menjadi 2 kategori, pertama kejahatan yang dilakukan oleh

75 Barda Nawawi Arief, Masalah Penegakan Hukum dan Kebijakan Hukum Pidana dalam Penanggulangan Kejahatan, Jakarta: Kencana, 2010, halm. 183. 
pemegang dan Kejahatan yang ditujukan terhadapsistem kekuasaan. Pendapat inilah yang penulis anggap sangat mewakili terhadap semua pendapat dan sangat rasional. Pendapat ini juga yang nanti akan dijadikan rujukan penulis untuk menganalisa tentang kejahatan terhadap rahasia intelijen negara.

Tindak pidana yang berkaitan dengan rahasia intelijen negara adalah suatu istilah tindak pidana yang penulis rumuskan guna menyebut suatu tindak pidana yang ditujukan terhadap kerahasiaan intelijen negara.

Menurut Undang-undang Nomor 17 Tahun 2011 tentang Intelijen Negara, disebutkan beberapa pengertian tentang intelijen, intelijen negara, dan rahasia intelijen. Intelijen adalah pengetahuan, organisasi, dan kegiatan yang terkait dengan perumusan kebijakan, strategi nasional, dan pengambilan keputusan berdasarkan analisis dari informasi dan fakta yang terkumpul melalui metode kerja untuk pendeteksian dan peringatan dini dalam rangka pencegahan, penangkalan, dan penanggulangan setiap ancaman terhadap keamanan nasional76.

Intelijen Negara adalah penyelenggara Intelijen yang merupakan bagian integral dari sistem keamanan nasional yang memiliki wewenang untuk menyelenggarakan fungsi dan kegiatan Intelijen Negara. Rahasia Intelijen adalah informasi, benda, personel, dan/atau upaya, pekerjaan, kegiatan Intelijen yang dilindungi kerahasiaannya agar tidak dapat diakses, tidak dapat diketahui, dan tidak dapat dimiliki oleh pihak yang tidak berhak77.

Ruang lingkup intelijen negara di sebutkan dalam Pasal 7 yaitu: “(a) Intelijen dalam negeri dan luar negeri; (b) Intelijen pertahanan dan/atau militer; (c) Intelijen kepolisian; (d) Intelijen penegakan hukum; dan (e) Intelijen kementerian/lembaga pemerintah nonkementerian".

Sedangkan penyelenggara intelijen negara terdiri atas: (1) Badan Intelijen Negara; (2) Intelijen Tentara Nasional Indonesia; (3) Intelijen Kepolisian Negara Republik Indonesia; (4) Intelijen Kejaksaan Republik Indonesia; dan (5) Intelijen kementerian/lembaga pemerintah nonkementerian.

\footnotetext{
${ }^{76}$ Pasal 1 angka 1 UU Nomor 17 Tahun 2011 tentang Intelijen Negara.

${ }^{77}$ Pasal 1 angka 2 dan 6 UU Nomor 17 Tahun 2011 tentang Inteijen Negara.
} 
Berbagai pengertian dasar di atas dapat ditarik kesimpulan tentang pengertian tindak pidana yang berkaitan dengan rahasia intelijen negara adalah suatu tindak pidana yang berkaitan rahasia intelijen negara yang perbuatannya sebagaimana disebutkan dalam Pasal 44-47 Undang-Undang Nomor 17 Tahun 2011 tentang Intelijen Negara, antara lain Mencuri rahasia negara, Membuka rahasia negara, Membocorkan rahasia negara.

Dilihat dari kegiatan tindak pidana yang berkaitan dengan rahasia negara tersebut sangat terkait dengan sistem kekuasaan maupun dapat dilakukan oleh aparat intelijen yaitu penguasa itu sendiri,maka jelas tindak pidana ini dapat dikatakan sebagai tindak pidana politik.

\section{Pengaturan Tindak Pidana yang Berkaitan dengan Intelijen Negara}

\section{Pengaturan di KUHP}

KUHP telah mengatur tentang tindak pidana yang berkaitan dengan kerahasiaan intelijen negara, hanya saja pengaturannya lebih pada taktis mengenai dokumen, surat-surat negara yang wajib dirahasiakan. Pasal-pasal yang mengatur tentang tindak pidana tersebut tersebar dalam 2 Bab yaitu Bab I tentang Kejahatan terhadap Keamanan Negara, dan Bab XVII tentang Membuka Rahasia. Bunyi pasal tersebut antara lain:

\section{Pasal 112}

Barang siapa dengan sengaja mengumumkan surat-surat, berita-berita atau keterangan- keterangan yang diketahuinya bahwa harus dirahasiakan untuk kepentingan negara, atau dengan sengaja memberitahukan atau memberikannya kepada negara asing, diancam dengan pidana penjara paling lama tujuh tahun.

\section{Pasal 113}

(1) Barang siapa dengan sengaja, untuk seluruhnya atau sebagian mengumumkan, atau memberitahukan maupun menyerahkan kepada orang yang tidak berwenang mengetahui, surat-surat, peta-peta, rencana-rencana, gambar-gambar atau benda-benda yang bersifat rahasia yang bersangkutan dengan pertahanan atau keamanan Indonesia terhadap serangan dari luar, yang ada padanya atau yang 
isinya, bentuknya atau susunanya benda- benda itu diketahui olehnya, diancam dengan pidana penjara paling lama empat tahun.

(2) Jika surat-surat atau benda-benda ada pada yang bersalah, atau pengetahuannya tentang itu karena pencariannya, pidananya dapat ditambah sepertiga.

\section{Pasal 114}

Barang siapa karena kesalahannya (kealpaannya) menyebabkan suratsurat atau benda-benda rahasia sebagaimana yang dimaksudkan dalam pasal 113 harus menjadi tugasnya untuk menyimpan atau menaruhnya, bentuk atau susunannya atau seluruh atau sebagian diketahui oleh umum atau dikuasai atau diketahui oleh orang lain (atau) tidak berwenang mengetahui, diancam dengan pidana penjara paling lama satu tahun enam bulan atau pidana kurungan paling lama satu tahun atau pidana denda paling tinggi empat ribu lima ratus rupiah.

\section{Pasal 115}

Barang siapa melihat atau membaca surat-surat atau benda-benda rahasia sebagaimana dimaksud dalam pasal 113, untuk seluruhnya atau sebagian, sedangkan diketahui atau selayaknya harus diduganya bahwa benda-benda itu tidak dimaksud untuk diketahui olehnya, begitu pula jika membuat atau menyuruh membuat salinan atau ikhtisar dengan huruf atau dalam bahasa apa pun juga, membuat atau menyuruh buat teraan, gambaran atau jika tidak menyerahkan benda-benda itu kepada pejabat kehakiman, kepolisian atau pamongh praja, dalam hal benda-benda itu ke tangannya, diancam dengan pidana penjara palling lama tiga tahun.

\section{Pasal 116}

Permufakatan jahat untuk melakukan kejahatan sebagaimana diamksud dalam pasal 113 dan 115, diancam dengan pidana penjara paling lama satu atahun.

\section{Pasal 322}

Barang siapa dengan sengaja membuka rahasia yang wajib disimpannya karena jabatan atau pencariannya, baik yang sekarang maupun yang dahulu, diancam dengan pidana penjara paling lama sembilan bulan atau pidana denda paling banyak sembilan ribu rupiah. Jika kejahatan dilakukan terhadap seorang tertentu, maka perbuatan itu hanya dapat dituntut atas pengaduan orang itu. 
Dari pasal-pasal KUHP di atas dapat ditarik kesimpulan bahwa yang dijadikan subyek pelaku tindak pidana adalah setiap orang baik dengan sengaja maupun tidak sengaja melakukan perbuatan-perbuatan tersebut di atas. Memang dalam KUHP belum mengenal adanya korporasi sebagai subyek hukum. Pasalpasal KUHP ini masih tetap berlaku karena belum ada aturan baru yang membatalkan Pasal ini. Akan tetapi apabila perbuatan dapat digolongkan Pasalpasal dalam Undang-undang baru, maka yang dipakai adalah undang-undang baru (lex specialis derogat lex generalis).

2. Pengaturan di Undang-undang Intelijen Negara

Undang-Undang Nomor 17 Tahun 2011 tentang Intelijen Negara mengatur tindak pidana terhadap rahasia intelijen negara dalam ketentuan BAB IX tentang ketentuan pidana yaitu dari Pasal 44 sampai 47. Selengkapnya bunyi pasal tersebut yaitu:

\section{Pasal 44}

Setiap Orang yang dengan sengaja mencuri, membuka, dan/atau membocorkan Rahasia Intelijen sebagaimana dimaksud dalam Pasal 26 dipidana dengan pidana penjara paling lama 10 (sepuluh) tahun dan/atau pidana denda paling banyak Rp500.000.000,00 (lima ratus juta rupiah).

\section{Pasal 45}

Setiap Orang yang karena kelalaiannya mengakibatkan bocornya Rahasia Intelijen sebagaimana dimaksud dalam Pasal 26 dipidana dengan pidana penjara paling lama 7 (tujuh) tahun dan/atau pidana denda paling banyak Rp300.000.000,00 (tiga ratus juta rupiah).

\section{Pasal 46}

Setiap Personel Intelijen Negara yang membocorkan upaya, pekerjaan, kegiatan, Sasaran, informasi, fasilitas khusus, alat peralatan dan perlengkapan khusus, dukungan, dan/atau Personel Intelijen Negara yang berkaitan dengan penyelenggaraan fungsi dan aktivitas Intelijen Negara sebagaimana dimaksud dalam Pasal 18 huruf b dipidana dengan pidana penjara paling lama 10 (sepuluh) tahun dan/atau pidana denda paling banyak Rp500.000.000,00 (lima ratus juta rupiah). 
Dalam hal tindak pidana sebagaimana dimaksud pada ayat (1) dilakukan oleh Personel Intelijen Negara dalam keadaan perang dipidana dengan ditambah 1/3 (sepertiga) dari masing-masing ancaman pidana maksimumnya.

\section{Pasal 47}

Setiap Personel Intelijen Negara yang melakukan penyadapan di luar fungsi penyelidikan, pengamanan, dan penggalangan sebagaimana dimaksud dalam Pasal 32 dipidana dengan pidana penjara paling lama 5 (lima) tahun dan/atau pidana denda paling banyak Rp500.000.000,00 (lima ratus juta rupiah).

Rumusan pasal di atas sangatlah umum akan tetapi dengan rumusan yang umum seperti itu akan mempermudah peraturan dalam operasionalisasi. Unsurunsur tidak pidana sebagaimana disebutkan dalam pasal-pasal di atas adalah:

(1) setiap orang (perseorangan atau badan hukum) dan/atau personil pengendali intelijen negara;

(2) dengan sengaja/kelalaian;

(3) melakukan perbuatan-perbuatan:

- mencuri, membuka, dan/atau membocorkan Rahasia Intelijen sebagaimana dimaksud dalam Pasal 26 (perbuatan ini untuk subyek setiap orang),

- membocorkan upaya, pekerjaan, kegiatan, Sasaran, informasi, fasilitas khusus, alat peralatan dan perlengkapan khusus, dukungan, dan/atau Personel Intelijen Negara yang berkaitan dengan penyelenggaraan fungsi dan aktivitas Intelijen Negara sebagaimana dimaksud dalam Pasal 18 huruf b (untuk subyek personil intelijen negara),

- melakukan penyadapan di luar fungsi penyelidikan, pengamanan, dan penggalangan sebagaimana dimaksud dalam Pasal 32 (untuk subyek personil intelijen).

Pasal-pasal ketentuan pidana tersebut menyebut Pasal 26 dan pasal 18 (b), serta Pasal 32 UU Intelijen. Untuk mendapatkan pemahaman yang utuh maka berikut ini bunyi pasal tersebut: 
Setiap Personel Intelijen Negara wajib merahasiakan seluruh upaya, pekerjaan, kegiatan, Sasaran, informasi, fasilitas khusus, alat peralatan dan perlengkapan khusus, dukungan, dan/atau Personel Intelijen Negara yang berkaitan dengan penyelenggaraan fungsi dan aktivitas Intelijen Negara;

\section{Pasal 26}

Setiap Orang atau badan hukum dilarang membuka dan/atau membocorkan Rahasia Intelijen.

Pasal 32

(1) Penyadapan sebagaimana dimaksud dalam Pasal 31 dilakukan berdasarkan peraturan perundangan-undangan.

(2) Penyadapan terhadap Sasaran yang mempunyai indikasi sebagaimana dimaksud dalam Pasal 31 dilaksanakan dengan ketentuan:

a. untuk penyelenggaraan fungsi Intelijen;

b. atas perintah Kepala Badan Intelijen Negara; dan

c. jangka waktu penyadapan paling lama 6 (enam) bulan dan dapat diperpanjang sesuai dengan kebutuhan.

(3) Penyadapan terhadap Sasaran yang telah mempunyai bukti permulaan yang cukup dilakukan dengan penetapan ketua pengadilan negeri.

Apabila memenuhi unsur-unsur di atas, maka dapat dipidana. Pidana pemberatan juga dikenakan jika perbuatan dengan subyek personil intelijen negara dilakukan pada saat keadaan perang.

\section{Pengaturan Tindak Pidana yang Berkaitan dengan Intelijen Negara di Masa yang Akan Datang}

Pengaturan tindak pidana yang berkaitan dengan intelijen negara ada beberapa kelemahan yang perlu dievaluasi, antara lain:

a) tidak ada kualifikasi bahwa jenis tindak pidana yang berkaitan dengan intelijen negara negara merupakan kejahatan atau pelanggaran; hal ini membuat kelemahan yuridis sendiri jika terjadi percobaan, pembantuan dan recidivis serta daluarsa. 
b) tidak ada pengaturan tentang permufakatan jahat, sehingga jika terjadi permufakatan jahat maka tidak ada penyelesaiannya. Permasalahan ini akan muncul dikarenakan permufakatan jahat berada di BAB IX KUHP, sehingga tidak berlaku terhadap Undang-Undang di luar KUHP.

c) tidak ada pengaturan tentang pedoman pidana denda yang tidak dibayar oleh korporasi. Hal ini membuat kerancuan yuridis tersendiri karena dalam KUHP hanya ada subyek hukum orang sehingga pengaturan kurungan pengganti hanya untuk subyek hukum orang.

Melihat kelemahan-kelemahan tersebut, maka kedepan kebijakan formulasi hukum pidana pada masa yang akan datang harus mencantumkan: (1) kualifikasi tindak pidana; (2) pengaturan tentang permufakatan jahat; (3) pedoman pelaksanaan pidana denda untuk korporasi.

\section{Penutup}

\section{Simpulan}

Pembahasan di atas dapat diambil kesimpulan (1) tindak pidana yang berkaitan dengan rahasia intelijen negara merupakan tindak pidana politik, hal ini karena dilakukan terhadap kekuasaan atau oleh pemegang kekuasaan yaitu personil intelijen; (2) pengaturan tindak pidana yang berkaitan dengan rahasia intelijen di Indonesia terdapat dalam KUHP dan Undang-Undang Nomor 17 Tahun 2011 dan kedua-duanya masih berlaku; (3) kebijakan formulasi tindak pidana terhadap intelijen negara yang akan datang harus menjawab kelemahankelemahan yang ada yaitu dengan mencantumkan kualifikasi tindak pidana, pengaturan permufakatan jahat, dan pedoman pelaksanaan pidana denda terhadap korporasi.

\section{Saran}

Saran penulis adalah (1) upaya pengaturan tindak pidana politik yang berkaitan dengan rahasia negara tidak perlu diperdebatkan panjang, karena hal ini sebagai sarana preventif atas tindakan maupun rong-rongan terhadap bangsa 
Indonesia dari pihak luar maupun dalam yang tidak suka terhadap negara ini; (2) upaya non penal sebagai usaha preventif terhadap tindak pidana yang berkaitan dengan kemanaan negara perlu di tingkatkan misalnya dengan meningkatkan kewaspadaan masyarakat bangsa,mencerdaskan kehidupan bangsa, meningkatkan taraf ekonomi masyarakat, penyadaran melalui aparatur daerah yang terkait. 


\section{DAFTAR PUSTAKA}

Arief, Barda Nawawi. 2010. Bunga Rampai Kebijakan Hukum Pidana: Perkembangan Penyusunan Konsep KUHP Baru. Jakarta: kencana Prenada Media Group.

2010. Masalah Penegakan Hukum dan Kebijakan Hukum Pidana dalam Penanggulangan Kejahatan. Jakarta: Kencana.

. 2012. Kebijakan Formulasi Ketentuan Pidana dalam Peraturan Perundang-undangan. Semarang:Penerbit Pustaka Magister.

Asshiddiqie, Jimly. 2010. Konstitusi dan Konstitusionalisme Indonesia, Jakarta: Sinar Grafika.

Hidayat, Arief. 2011. Sari Kuliah Politik Hukum. SPP MIH Undip.

Nusantara, Abdul Hakirn Garuda. Pidana Politik Seri Diskusi Hukum dan Politik, Devisi Pendidikan dan Kajian Strategis Yayasan Lembaga Bantuan Hukum Indonesia (YLBHI). Jakarta

Syamsuddin, Aziz. 2011. Tindak Pidana Khusus. Jakarta: Sinar Grafika.

\section{Peraturan Perundang-undagan}

Kitab Undang-Undang Hukum Pidana

Undang-Undang Nomor 17 Tahun 2011 tentang Intelijen Negara (Lembaran Negara Tahun 2011Nomor 105, Tambahan Lembaran Negara Nomor 5249)

Internet

http://sosbud.kompasiana.com/2011/03/01/20-keunggulan-indonesia-di-dunia diunduh pada tanggal 19 Mei 2012. 